\title{
Fen Bilimleri ve Sosyal Bilgiler Öğretim Programlarının Çevre Eğitimi Açısından Değerlendirilmesi
}

\author{
Saim TURAN \\ Akdeniz Üniversitesi \\ saimturan@akdeniz.edu.tr \\ Adem KOÇ \\ Mersin Üniversitesi \\ ademkoc@mersin.edu.tr
}

Gönderilme Tarihi: 16/03/2021

Kabul Tarihi: 30/07/2021

Yayınlanma Tarihi: 30/07/2021

\begin{tabular}{|c|c|}
\hline Makale Bilgileri & ÖZET \\
\hline $\begin{array}{l}\text { Anahtar Kelimeler: } \\
\text { Çevre eğitimi, } \\
\text { Fen bilgisi eğitimi, } \\
\text { Sosyal bilgiler } \\
\text { eğitimi }\end{array}$ & $\begin{array}{l}\text { Araştırmanın amacı ilk ve orta öğretim bazında } 2018 \text { yılında güncellenerek } \\
\text { uygulamaya konulan fen bilimleri ve sosyal bilgiler dersi öğretim } \\
\text { programlarının çevre eğitimi açısından analiz edilmesidir. İfade edilen amaca } \\
\text { yönelik olarak araştırmada veriler, araştırmaya uygunluk açısından nitel } \\
\text { yöntem kullanılarak elde edilmiştir. Bu bağlamda araştırma, görsel ve yazılı } \\
\text { materyallerin derinlemesine incelenmesine olanak sağlayan doküman inceleme } \\
\text { desenine göre gerçekleştirilmiştir. Araştırma kapsamında öğretim } \\
\text { programlarında yer alan özel amaçlar, yetkinlikler, değerler, beceriler ve } \\
\text { kazanımların yer aldığı konu ve öğrenme alanları çevre eğitimi bağlamında } \\
\text { incelenmiş ve elde edilen bulgular ayrı başlıklar altında açıklanarak } \\
\text { sunulmuştur. Her iki öğretim programında belirlenen özel amaçlar içerisinde } \\
\text { doğrudan çevre eğitimine yönelik özel amaçların yer aldığı görülürken, ortak } \\
\text { olarak ifade edilen yetkinlikler bağlamında doğrudan çevre eğitimi ile ilişki } \\
\text { kurmanın mümkün olmadığı görülse de bunların bütünlük içerisinde çevre } \\
\text { eğitiminde önemli olabileceği düşünülmektedir. Öğretim programlarında yer } \\
\text { alan becerilerin alana özgü beceriler olarak ifade edildiği görülmekte, sosyal } \\
\text { bilgiler programında doğrudan çevre eğitimine ilişkin beceri olduğu } \\
\text { görülürken fen bilimleri programında rastlanmadığı görülmektedir. Son olarak } \\
\text { konu ve öğrenme alanları altında ifade edilen kazanımlar incelendiğinde her iki } \\
\text { öğretim programında her sınıf düzeyinde çevre eğitimine yönelik kazanıma } \\
\text { mutlaka yer verildiği görülmektedir. Bu bağlamda ifade edilen bu iki disiplinin } \\
\text { öğretim programlarında çevre eğitimine yer verilme durumu çeşitli yönleriyle } \\
\text { incelenmeye çalışırlarak, bireylere çevre eğitimi verilmesi konusundaki önemi } \\
\text { ortaya konulmaya çalışılmıştır. }\end{array}$ \\
\hline
\end{tabular}

Turan, S., \& Koç, A. (2021). Fen bilimleri ve sosyal bilgiler öğretim programlarının çevre eğitimi açısından değerlendirilmesi. Gazi Eğitim Bilimleri Dergisi, 7(2), 178-195. https://dx.doi.org/10.30855/gjes.2021.07.02.004

Dergi Web Sayfast: http://dergipark.gov.tr/gebd 


\section{Evaluation of Science Education and Social Sciences Curriculums in terms of Environmental Education}

\begin{tabular}{ll}
\hline \hline Article Info & ABSTRACT \\
\hline Keywords: & The aim of the research is to analyze the science education and social studies \\
Environmental & course curriculums, which were updated and implemented in 2018 in primary \\
education, & and secondary education, in terms of environmental education. For the stated \\
Science education, & purpose and in terms of suitability to the research, the data were collected by \\
Social studies & using the qualitative method. In this context, the research was carried out \\
education & according to the document analysis research design, which allows in-depth \\
analysis of visual and written materials. Within the scope of the research, special & aims, competencies and values, subject and learning areas in the curriculums \\
are examined in the context of environmental education. Findings obtained from & the research are presented under separate titles. According to the results, it has \\
been observed that special aims directly related to environmental education are \\
included among the special purposes determined in both curricula. However, \\
the competencies in both curricula were not found directly related to \\
environmental education. Yet, it is thought that competencies can be important \\
in environmental education in integrity. It is seen that the skills in the teaching \\
programs are expressed as skills specific to the field, while it is observed that \\
there is a skill for direct environmental education in the social studies \\
curriculum, there is no skill for direct environmental education in the science \\
curriculum. Finally, when the acquisitions expressed under subject and learning \\
areas are examined, it is seen that both education programs include the \\
acquisition towards environmental education at each grade level. In this context, \\
the inclusion of environmental education in the curriculum of these two \\
disciplines has been tried to be examined in various aspects, and the importance \\
of environmental education to individuals has been tried to be revealed.
\end{tabular}

\section{GİRIŞ}

En genel tanımıyla çevre canlı ve cansız varlıkların sürekli bir etkileşim içerisinde bulunarak varlıklarını sürdürmüş oldukları dinamik bir ortam olarak ifade edilmektedir (Akdur, 2005). İnsanı da içinde barındıran çevre, ifade edilen bu genel tanım çerçevesinde geliştirilen daha birçok tanım ile de nitelendirilmektedir. İçerisinde insanın yer alması nedeniyle sosyal ve kültürel öğelerin yanı sıra canlı varlıkların her türlü etkileşimine yön veren fiziksel, kimyasal ve biyolojik unsurları da içerisinde barındıran çevre (Cansaran ve Yıldırım, 2014), bu yönüyle çok boyutlu bir yapıya sahiptir. Bu durum da çevrenin birçok disiplin ile etkileşim içerisinde olması yani disiplinler arası bir kavram olması sonucunu ortaya çıkarmaktadır (Atasoy, 2015). Çevrenin birçok unsuru bünyesinde barındıran disiplinler arası bir kavram olmasının sonucu olarak da, bu disiplinlerde meydana gelen gelişmelerden olumlu veya olumsuz olarak etkilendiği görülmektedir. Özellikle 21. yüzyıl ile birlikte yaşanan hızlı nüfus artışı, bilim ve teknoloji ile sanayi alanında yaşanan gelişmelerin çevre üzerindeki olumsuz etkilerinin de oldukça fazla olduğu görülmektedir. Yaşamını sürdürebilmek için doğaya son derece bağımlı olan insanlığın da varlığını sağlıklı bir şekilde devam ettirebilmek için doğada karşılaştığı sorunlara çözüm 
üretmesi gerekmektedir (Üçüncü \& Yllmaz, 2019). Bu durum çevrenin sürdürülebilirliği ve gelecek kuşaklara daha yaşanılabilir bir çevre için çevre eğitiminin gerekliliği ve önemini de ayrıca gözler önüne sermektedir (Eroğlu ve Yıldırım, 2020; Muşlu Kaygısız, 2020).

Çevrenin genel olarak insan faaliyetlerinden etkilendiği düşünüldüğünde çevre eğitimine yönelik olarak da öncelikle bireylerin gerekli tutum, değer, bilgi ve beceriler ile donatılması gerektiği düşünülmektedir (Muşlu Kaygısız, 2020). Çevrenin disiplinler arası yapısı gereği çevre eğitimi de, çevre ile ilgili konularda gerekli bilinç seviyesinde olarak, oluşan sorunların çözümünde aktif görev alan ve yeni sorunların ortaya çıkmasını engellemeye yönelik davranışlar sergileyen bir toplum oluşturma amaciyla hayat boyu süren çok boyutlu bir yaklaşım olarak ifade edilmektedir (Moseley, 2000). Bu anlamda 1978 yılında gerçekleştirilen Tiflis konferansında da çevre eğitiminin genel amacının bireylere çevre okuryazarlığı kazandırmak olduğu ifade edilmiştir. Bu bağlamda çevre okuryazarlığı da bireylerin sahip oldukları bilgileri tutum, değer ve becerilerle birleştirerek davranışa dönüştürmelerini gerektirmektedir (Goldman, Yavetz ve Pe'er, 2006).

Bireylerin çevre okuryazarı bireyler olarak yetişmelerinin sağlanması ve edindikleri bilginin davranışa dönüşmesinin sağlanması için de en uygun ortamın sınıf ortamı olduğu düşünülmektedir. Bu bağlamda, çevre eğitiminin disiplinler arası yapısı gereği çeşitli eğitim ve öğretim programları içerisinde kendisine yer bulduğu görülmektedir. Okul öncesi eğitim programı ile hayat bilgisi, fen bilimleri ve sosyal bilgiler öğretim programları okul öncesi, ilk ve ortaokul düzeyinde bünyesinde çevre eğitimine yönelik çeşitli kazanımları barındıran dersler olarak dikkat çekmektedir (Bahar, Erdaş ve Özel, 2013; Muşlu Kaygısız, 2020; Öztürk ve Zayimoğlu Öztürk, 2015). Bu durumda, eğitim programı ve öğretim programı kavramlarının anlaşılması da ayrıca önem arz etmektedir.

Tüm ülkeler bireylere okul içinde ve okul dışında bireylerin deneyimlemiş oldukları öğrenim yaşantılarını içinde barındıran, kapsamlı ve detaylı bir planlanmış faaliyetler dizisi sunmaktadır. Eğitim programı olarak adlandırılan bu planlı faaliyetler dizisi her bir ülkenin milli eğitim teori ve politikaları çerçevesinde oluşturulmakta ve uygulamaya konulmaktadır. Hazırlanan bu eğitim programları genellikle; "bireyleri niçin eğitiyoruz?" sorusunun cevabı olarak "hedef"; "bireylerin belirlenen hedeflere ulaşması için neleri öğrenmesi gerekiyor?" sorusunun cevabı olarak "içerik"; "belirlenen hedeflere ulaşmak için içerik nasıl öğretilmeli?" sorusunun cevabı olarak "öğrenme-öğretme durumları" ve "belirlenen hedeflere ne kadar ulaşıldı?" sorusunun cevabı olarak "sınama durumları" olmak üzere dört temel unsur çerçevesinde oluşturulmaktadır. Bununla birlikte eğitim programları temel alınarak oluşturulan fakat eğitim programları kadar geniş kapsamlı olmayan programlar da bulunmaktadır (Aksoy ve Taşkın, 2019). 
Öğretim programı olarak adlandırılan bu program türleri öğrencilere kazandırılması planlanan hedefler, bu hedeflere yönelik konular ve konuların içerikleri, konu içeriklerinin öğrencilere aktarılmasında faydalanılan öğretim yöntem ve teknikleri, öğretim teknolojileri ile hedeflere ulaşılma durumlarını gösteren ölçme değerlendirme yaklaşımlarını içermektedir (Görgen,2014; Özçelik, 2014; Şardă̆, 2020). Eğitim programı ve öğretim programından sonra kapsam olarak daha dar olan bir program ise ders programıdır. Ders programları öğretim programları içerisinde yer alan derslere ilişkin hazırlanan program türüdür (Taşpınar, 2017).

Ülke genelindeki eğitim öğretim faaliyetlerinin standartlaştırılmasını sağlayan öğretim programlarının uygulamaya konulması neticesinde elde edilen dönütlere göre de ülkeler eğitim politikalarını şekillendirmektedir (Aksoy ve Taşkın, 2019). 21. yüzyılda hızla değişen ve gelişen bilim ve teknoloji ile birlikte eğitim sistemlerinin ve dolayısıyla öğretim programlarının da güncellenmesini gerektirmektedir. Ülkeler öğretim programlarını çağın şartlarına uygun hale getirerek bireyleri 21. yüzyılın gerektirdiği bilgi ve becerilerle donatmayı amaçlamaktadırlar (Çıray, Küçükyılmaz ve Güven, 2015).

Öğretim programlarının disiplinler arası yapısı da göz önüne alınarak incelendiğinde özellikle ilk ve orta öğretimde disiplinler arası dersler olarak göze çarpan fen bilimleri ve sosyal bilgiler derslerine ilişkin programın yapısını oluşturan öğeler bakımından ortak olduğu noktalar göze çarpmaktadır. Bu ortak noktalardan birisi ve geniş kapsamlı olanı ise çevre eğitimidir. Hızlı değişim ve gelişimlerin yaşandığı 21. yüzyılın ayrıca çevre sorunlarını da beraberinde getirdiği görülmektedir. Bu bağlamda sürdürülebilir bir çevre için çevre eğitimin son derece önemli olduğu görülmektedir (Teksöz, Şahin ve Ertepınar, 2010). “Yeryüzü, bize atalarımızdan miras kalmadı çocuklarımızdan ödünç aldık" anlayışı doğrultusunda baktığımızda gelecek kuşaklara yaşanılabilir bir çevre bırakmak zorunda olduğumuz açıktır.

Sürdürülebilir bir yaşam için çevrenin korunması ve gelecek kuşaklara yaşanılabilir bir ortam sağlanması hususunda ise her birey hayati öneme sahiptir. Bireylerin çevrenin korunması ve sürdürülebilirliği konusunda bilinçli davranmaları da gerekli olan bilgi, beceri, değer ve tutumlarla donatılmasıyla sağlanabilmektedir (Muşlu Kaygısız, 2020). Bireylere gerekli bilgi, beceri, değer ve tutumların kazandırılması çocukluk döneminde ailede başlayarak devamında ise okul öncesi dönem ile birlikte okulda kazandırılmaya başlanmaktadır. Okul öncesi dönemden sonraki ilk ve ortaokul öğretim programları incelendiğinde çevreye yönelik konuların fen bilimleri ve sosyal bilgiler dersi kapsamında yer aldığı görülmektedir. Dolayısıyla geçmişten günümüze çeşitli değişikliklere uğramakla birlikte son öğretim programında yer alan adlarıyla fen bilimleri ve sosyal bilgiler adı altında okutulan ve disiplinler arası bir yapıya sahip olan derslerin bireylere gerekli çevre eğitiminin verilebilmesi açısından önemli bir yere sahip olduğu görülmektedir. 
Sosyal bilgiler dersi öğretim programının ülkemizde tarihsel gelişimi incelendiğinde ilk olarak 1968 yılında sosyal bilgiler adı altında okutulmaya başlandığı, bu yıla kadar farklı isimler altında okutulduğu ve çeşitli güncellemelere maruz kaldığı görülmektedir (Kaymakc1, 2009). 1968 yılını takiben 1980 yılında dersin adı Milli Tarih ve Milli Coğrafya olarak değiştirilmesine rağmen 1998 yılında yeniden sosyal bilgiler adıyla okutulmaya devam edildiği görülmektedir (Kan, 2010). Bu yılı takiben 2004 yılında, tüm öğretim programlarında olduğu gibi, köklü bir değişikliğe gidilerek yapılandırmacı yaklaşım benimsenmiş ve devamında 2017 yılında güncellenerek 2018 yılında yürürlüğe konulan günümüz sosyal bilgiler dersi öğretim programı şeklini aldığı görülmektedir (Çiftçi ve Akça, 2019).

Fen Bilimleri dersi öğretim programının da benzer şekilde süreç içerisinde çeşitli değişimlere uğradığı görülmektedir. Dersin ilk olarak fen ve tabiat bilgisi olarak okutulmaya başlandığı sonrasında ise gerçekleşen müfredat değiş̧ikleri ile birlikte fen bilgisi, fen ve teknoloji ve fen bilimleri adları ile okutulmaya devam edildiği görülmektedir. 1922 yılından itibaren okutulmaya başlandığı düşünülürse günümüzdeki son şeklini alana kadar 15 kez değişikliğe uğradığı ifade edilen fen bilimleri dersi öğretim programının bazen küçük revizyonlar geçirdiği bazense, yine tüm öğretim programlarında olduğu gibi, köklü değişikliklere uğradığı görülmektedir (Yıldırım, 2020).

Literatür incelendiğinde fen bilimleri ve sosyal bilgiler derslerine ait öğretim programlarının çevre konularına yönelik olarak farklı araştırmacılar tarafından incelendiği görülmektedir. Örneğin, Ürey ve Aydın tarafından 2014 yılında yapılan çalışmada dersin o dönemdeki adıyla fen ve teknoloji dersi öğretim programının analizini yaparak, fen ve teknoloji dersi içerisinde çevre eğitiminin mevcut durumunu ortaya koymaya çalışmışlardır. Akınoğlu ve Sarı tarafından 2009 yılında yapılan çalışmada ilköğretim programlarında yer alan çevre ile ilgili kazanımlar değerlendirilmiştir. Ateş (2019) yapmış olduğu çalışmada fen bilimleri dersi güncel programı olan 2018 öğretim programını analiz ederek programın amaçlarında sürdürülebilir kalkınmanın hangi boyutlarının ne düzeyde ele alındığını ve toplam kazanım içerisinde sürdürülebilir kalkınmaya ilişkin kazanımların oranının ne olduğunu ortaya koymaya çalışmıştır. Öztürk ve Zayimoğlu Öztürk tarafından 2015 yılında öğretim programının çevre eğitimi açısından analizinin yapıldığı çalışmada ise sosyal bilgiler dersi ele alınmış ve mevcut durum tasvir edilmeye çalışılmıştır.

Çevre eğitiminin yeri ve önemini disiplinler arası yaklaşımla karşılaştırmalı olarak ele alan çalışmalar ise ilköğretim anlamında Muşlu Kaygısız tarafından 2020 yılında gerçekleştirilen çalışma ve lisans öğretimi anlamında Yılmaz ve Sayhan tarafından 2018 yılında gerçekleştirilen çalışmalar olduğu görülmektedir. Muşlu Kaygısız gerçekleştirmiş olduğu çalışmasında çevre eğitiminin okul öncesinde ve fen bilimleri dersinde ne oranda yer aldığını ilgili eğitim ve öğretim 
programlarında yer alan temel öğeler bağlamında analiz ederken, Yılmaz ve Sayhan tarafından gerçekleştirilen çalışmada ise lisans öğretim programları düzeyinde sosyal bilgiler ve fen bilgisi programlarında çevre eğitimine yer verilme durumu karşılaştırmalı olarak incelenmiştir. Bu bağlamda, ilk ve ortaöğretim seviyesinde okutulan ve çevre eğitimini de içerisinde barındıran dersler olan fen bilimleri ve sosyal bilgiler derslerinin çevre eğitimi açısından önemli olduğu görülmektedir. Buradan hareketle ilgili derslere ilişkin 2018 yılında uygulanmaya başlanan öğretim programlarında çevre eğitiminin yer alma durumunun incelenmesi gerektiği düşünülmektedir. Ayrıca literatürde ilk ve orta öğretim düzeyinde okutulan ve disiplinler arası bir yapıya sahip olan fen bilimleri ve sosyal bilgiler derslerine ait öğretim programlarının karşılaştırmalı olarak ikisinin bir arada ele alındığı araştırmalara da rastlanmamıştır. Bu durumda gerek yapıları gerekse içerikleri bakımından ortak noktalara sahip olan bu programların çevre eğitimi açısından birlikte değerlendirilmesinin önemi ortaya çıkmaktadır.

Buradan hareketle gerçekleştirilen bu araştırmanın araştırmanın amac1, ilk ve orta öğretim düzeyinde 2018 yılında güncellenerek uygulamaya konulan fen bilimleri ve sosyal bilgiler dersi öğretim programlarının çevre eğitimi açısından değerlendirilmesidir. Bu amaca yönelik olarak araştırma, belirlenen şu alt araştırma soruları çerçevesinde gerçekleştirilmiştir: 2018 fen bilimleri ve sosyal bilgiler öğretim programlarında çevre eğitiminin;

1) Programlarda yer alan özel amaçlarla ilişkili olma durumu nedir?

2) Programlarda yer alan yetkinlikler, değerler ve becerilerle ilişkili olma durumu nedir?

3) Programlarda yer alan konu ve öğrenme alanlarındaki durumu nedir?

\section{YÖNTEM}

Araştırmada, araştırma sorusunun doğası gereği veriler nitel olarak elde edilmiştir. Araştırma, görsel ve yazılı materyallerin derinlemesine incelenmesine olanak sağlayan doküman inceleme desenine göre gerçekleştirilmiştir (Sönmez ve Alacapınar, 2018). Bu bağlamda 2018 fen bilimleri ve sosyal bilgiler dersi öğretim programı genel ve özel amaçlar, yetkinlikler, beceriler, değerler, konu ve öğrenme alanları ile kazanımlar açısından ayrıntılı bir şekilde incelenerek çevre eğitimine yer verilme durumları göz önüne serilmeye çalışılmıştır.

\section{Verilerin Elde Edilmesi}

Araştırma verilerinin toplanması amacıyla 2018 fen bilimleri ve sosyal bilgiler dersi öğretim programlarına Milli Eğitim Bakanlığı resmi internet sitesi aracılığıyla erişim sağlanmıştır. Erişim sağlanan ilgili öğretim programlarından araştırma soruları çerçevesinde gerekli veriler sağlanarak sunulmuştur. Fen Bilimleri ve Sosyal bilgiler dersi ğretim programlarının incelenmesinde araştırmacılar tarafından geliştirilen "öğretim programı veri 
toplama formu" kullanılmıştır. Veri toplama formu oluşturulmadan önce ilgili literatür taranarak öğretim programlarının incelenmesi için kullanılabilecek bir veri toplama aracı olup olmadığı belirlenmeye çalışılmıştır. Bu bağlamda geliştirilen öğretim programı formunda öğrenme alanı, ünite, kazanım, değer ve beceriler başlıkları altında verilerin toplanılması kararlaştırılmıştır.

\section{Verilerin Analizi}

Araştırmada elde edilen verilerin analizinde, nitel araştırma yöntemlerinden olan ve elde edilen bulguların betimlenerek yorumlanması için kullanılan (Yıldırım \& Şimşek, 2008) betimsel analizinden yararlanılmıştır. Araştırma kapsamında da veriler araştırma soruları bağlamında kategorilere ayrılarak ilgili kategorilerde çevre eğitimine yer verilme durumu ifade edilmeye çalışılmıştır. Araştırmada verilerin analizinde yapılan kodlamanın güvenirliğini sağlamak amacıyla üçgenleme (triangulation) yapılmıştır. Bu kapsamda incelenen programlar iki alan uzmanı akademisyen tarafından ayrı ayrı analiz edilmiştir.

\section{BULGULAR}

Bu bölümde 2018 yılında yayınlanan fen bilimleri ve sosyal bilgiler öğretim programlarında yer alan özel amaçlar, yetkinlikler, beceriler, değerler, konu ve öğrenme alanları ile kazanımlar çevre eğitimi bağlamında incelenmiş ve elde edilen bulgular aşağıda verilmiştir. Bu bağlamda 2018 fen bilimleri ve sosyal bilgiler öğretim programlarında çevre eğitiminin;

\section{Programlarda Yer Alan Özel Amaçlarla İlişkili Olma Durumu}

Özel amaçlar, genel amaçların oluşturulmasında dikkate alınan kanun, amaç ve ilkeler göz önünde bulundurularak alana özgü olarak oluşturulan hedef ve davranışlardan oluşmaktadır. $\mathrm{Bu}$ bağlamda çalışmaya konu olan fen bilimleri ve sosyal bilgiler dersi öğretim programları incelendiğinde fen bilimleri dersi öğretim programına ilişkin 10 tane; sosyal bilgiler dersi öğretim programına ilişkin 18 tane özel amacın yer aldığı görülmektedir. Bu özel amaçlardan fen bilimleri dersi öğretim programında yer alan 2 amacın, sosyal bilgiler dersi öğretim programında yer alan 1 amacın çevre eğitimi ile ilişkili olduğu saptanıştır.

Bu açıdan bakıldığında fen bilimleri dersi öğretim programında yer alan 10 özel amaçtan;

“2. Doğanın keşfedilmesi ve insan-çevre arasındaki ilişkinin anlaşılması sürecinde, bilimsel süreç becerileri ve bilimsel araştırma yaklaşımını benimseyip bu alanlarda karşılaşılan sorunlara çözüm üretmek, 3. Birey, çevre ve toplum arasındaki karşılıklı etkileşimi fark ettirmek; toplum, ekonomi ve doğal kaynaklara ilişkin sürdürülebilir kalkınma bilincini geliştirmek (MEB, 2018)," amaçları ile, sosyal bilgiler dersi öğretim programında yer alan 18 özel amaçtan; “6. Doğal çevrenin ve kaynakların sınırlılığının farkına varıp çevre duyarlılığı içerisinde doğal kaynakları korumaya çalışmaları ve sürdürülebilir bir çevre anlayışına sahip olmaları (MEB, 2018)," 
amacının doğrudan çevre eğitimi ile ilişkili olduğu söylenebilir.

\section{Programlarda yer alan yetkinlikler, değerler ve becerilerle ilişkili olma durumu}

Öğretim programlarında yer alan ve ortak olarak ifade edilen yetkinlikler ile çevre eğitimi arasında doğrudan ilişki kurmanın mümkün olmadığı görülse de bunların bütünlük içerisinde çevre eğitiminde önemli olabileceği düşünülmektedir.

Çok boyutlu bir yapıya sahip olan değerler içerisinde sosyal, siyasi, ekonomik, ahlaki, dini ve pedagojik konular yer almaktadır (Erk1lı̧, 2019). Bu bağlamda değerlerin toplumun sahip olduğu temel ilke ve inançları ifade ettiği söylenebilmektedir (Halstead \& Taylor, 2000). Bütün eğitim sürecinin ruhu olarak ifade edilen değerlerimizin öğretim programlarında ayrı bir öğrenme alanı, ünite veya konu olarak yer almadığı bunun yerine her bir öğretim programının her birinde yer aldığı ifade edilmektedir (MEB, 2018). Öğretim programlarında yer alan ve kök değerler olarak ifade edilen değerlerin; "Adalet", "Aile birliğine önem verme", "Bağımsızlık", "Barış", "Bilimsellik", "Çalışkanlık", "Dayanışma", "Duyarlılık", "Dürüstlük", "Estetik", "Eşitlik", “Özgürlük", "Sayg1", "Sevgi”, “Sorumluluk", “Tasarruf", “Vatanseverlik" ve "Yardımseverlik" olmak üzere 18 tane olduğu görülmektedir (MEB, 2018). Bu değerlerden duyarlılık, sorumluluk, tasarruf ve vatanseverlik değerlerinin çevre eğitimi ile ilişkili oldukları saptanmıştır.

Öğretim programlarında yer alan temel becerilerin genel olarak alana özgü beceriler olarak ifade edildiği görülmekle birlikte öğretim programları incelendiğinde disiplinler arasında ortak becerilere de rastlamak mümkündür. Bu bağlamda bilginin eyleme dönüşmesi olarak ifade edilebilen becerilerin (Turan, 2019) bütüncül olarak kazanılabilmesi için disiplinler arası çalışmaların önemli olduğu açıktır. İlk ve ortaöğretim düzeyinde disiplinler arası dersler olarak göze çarpan fen bilimleri ve sosyal bilgiler derslerinin ayrıca bu açıdan da son derece önemli bir yere sahip olduğu düşünülmektedir. Fen bilimleri dersi öğretim programinda alana özgü becerilerin "bilimsel süreç becerileri", "yaşam becerileri" ve "mühendislik ve tasarım becerileri" olmak üzere üç ana başlık altında toplandığı görülmektedir. İfade edilen bu becerilerin doğrudan çevreye yönelik olduğu düşünülmemekle birlikte, bireylerin çevrelerinde karşılaştıkları ve çevreyle ilgili herhangi bir soruna çözüm önerileri geliştirebilmeleri açısından oldukça önemli olduğu düşünülmektedir. Sosyal bilgiler dersi öğretim programında 27 temel beceri bulunmaktadır. Bu becerilerden "çevre okuryazarlı̆̆ı" nın doğrudan, "değişim ve sürekliliği algılama", "empati" ve "mekânı algılama" becerilerinin de dolaylı olarak çevre eğitimiyle ilişkilendirilebilecek beceriler olduğu söylenebilir. 


\section{Programlarda Yer Alan Konu ve Öğrenme Alanlarında Yer Alma Durumu}

Konu ya da öğrenme alanı birbiri ile ilişkili bilgi, beceri ve değerlerin bir bütün olarak görülebilmesine yardımcı olan, öğrenmeyi organize eden disiplinler arası bir yapı olarak ifade edilmektedir (MEB, 2018). Fen bilimleri dersi öğretim programında konu alanı olarak ifade edilen “Dünya ve Evren”, “Canlılar ve Yaşam”, “Fiziksel Olaylar” ve “Madde ve Doğası” olmak üzere 4 bölüm göze çarparken bu konu alanlarının sınıf düzeylerine göre farklı ünite adları ile ifade edildiği görülmektedir. Sosyal bilgiler dersi öğretim programında yer alan öğrenme alanları "Birey ve Toplum”, “Kültür ve Miras”, “İnsanlar, Yerler ve Çevreler”, “Bilim, Teknoloji ve Toplum”, “Üretim, Dağıtım ve Tüketim” ve “Etkin Vatandaşlık ve Küresel Bağlantılar”" olmak üzere 7 tanedir.

Fen bilimleri dersi öğretim programında yer alan "Dünya ve Evren" konu alanında sınıf düzeyine göre farklılaşmakla birlikte toplam 6 ünite yer aldığ görülmektedir. Üniteler göz önünde bulundurulduğunda bu konu alanı ile öğrencilere güneş sistemi ve güneş sisteminde yer alan gezegenler, gezegenlerin hareketleri ve bu hareketlerinin sonuçlarının kazandırılmaya çalışıldığ1 görülmektedir. "Canlılar ve Yaşam" konu alanında yine sınıf düzeyine göre farklılaşmakla birlikte toplam 12 ünite yer aldığı görülmektedir. Daha fazla ünite sayısına sahip olan bu konu alanında öğrencilere vücudumuzda yer alan organ ve sistemler ve bunların sağlığından canlılar dünyasının diğer üyeleri ve besinlerimize kadar temelde canlılar ve yaşamsal olaylar ile ilgili bilgi ve beceriler kazandırılmaya çalışıldığı görülmektedir. Bir diğer konu alanı olan "Fiziksel Olaylar" konu alanı ise en fazla ünite sayısı ile temsil edilen konu alanı olarak göze çarpmaktadır. Toplam 18 ünitenin yer aldı̆̆ı konu alanında öğrencilere kuvvet ve kuvvetin etkilerinden elektrik ve ışığa kadar oldukça geniş bir yelpazede bilgi ve becerilerin kazandırılmasının amaçlandığı görülmektedir. Fen bilimleri dersi öğretim programında yer alan dördüncü ve son konu alanı olan "Madde ve Doğası" konu alanı da yine "Dünya ve Evren" konu alanında olduğu gibi 6 tane ünite ile temsil edilmektedir. Konu alanında yer alan üniteler göz önünde bulundurulduğunda öğrencilerin madde ve maddenin özelliklerinden, karışım ve değişimlere kadar çeşitli konularda bilgi ve beceri sahibi olmasının amaçlandığı görülmektedir (MEB, 2018).

Fen bilimleri dersi öğretim programında yer alan konu alanları ve bu konu alanları altında yer alan ünite isimleri incelendiğinde toplamda ifade edilen 42 üniteden yalnızca bir tanesinin adında doğrudan "çevre" kavramının yer aldığı görülmektedir. İlk bakışta "Canlılar ve Yaşam" konu alanında yer alan ve 8. Sınıf düzeyinde ifade edilen "Enerji Dönüşümleri ve Çevre Bilimi" ünitesi çevreye yönelik olarak tek ünite olarak görülmesine rağmen diğer konu alanlarında yer alan kazanımlar incelendiğinde her konu alanında çevre eğitimine yönelik kazanıma yer verildiği görülmektedir. Ayrıca sınıf düzeyi olarak bakıldığında farklı konu 
alanları içerisinde her sınıf düzeyinde çevre eğitimine yönelik kazanıma yer verildiği görülmektedir.

Fen bilimleri dersinin okutulmaya başlandığı 3. sınıf düzeyinde "Dünya ve Evren" konu alanında "Dünya' nın yüzeyinde karaların ve suların yer aldığını kavrar”, “ Dünya yüzeyindeki kara ve suların kapladığı alanları model üzerinde karşılaştırır" kazanımlarının; "Canlılar ve Yaşam" konu alanında "Yaşadığı çevreyi tanır", "Yaşadığı çevrenin temizliğinde aktif görev alır", "Doğal ve yapay çevre arasındaki farkları açıklar", "Yapay bir çevre tasarlar", "Doğal çevrenin canlılar için öneminin farkına varır”, “Doğal çevreyi korumak için araştırma yaparak çözümler önerir" kazanımlarının ve "Fiziksel Olaylar" konu alanında yer alan "Pil atıklarının çevreye vereceği zararları ve bu konuda yapılması gerekenleri tarışıı" kazanımlarının doğrudan çevre eğitimine yönelik olduğu görülmektedir (MEB, 2018).

4. sınıf düzeyinde "Dünya ve Evren" konu alanında yer alan "Yer kabuğunun kara tabakasının kayaçlardan oluştuğunu belirtir", "Kayaçlarla madenleri ilişkilendirir ve kayaçların ham madde olarak önemini tartışı", "Fosillerin oluşumunu açıklar" kazanımlarının; "Fiziksel Olaylar" konu alanında yer alan "Işı kirliliğginin nedenlerini sorgular", "Işık kirliliğinin, doğal hayata ve gök cisimlerinin gözlenmesine olan olumsuz etkilerini açıklar", "Işık kirliliğini azaltmaya yönelik çözümler üretir", "Ses kirliliğinin nedenlerini sorgular", "Ses kirliliğinin insan sağlı̆̆1 ve çevre üzerindeki olumsuz etkilerini açıklar", "Ses kirliliğini azaltmaya yönelik çözümler üretir" kazanımlarının ve "Canlılar ve Yaşam" konu alanında yer alan "Kaynakların kullanımında tasarruflu davranmaya özen gösterir", "Yaşam için gerekli olan kaynakların ve geri dönüşümün önemini fark eder" kazanımlarının doğrudan çevre eğitimine yönelik olduğu görülmektedir (MEB, 2018).

5. sınıf düzeyine bakıldığında ise "Canlılar ve Yaşam" konu alanında yer alan "Biyoçeşitliliğin doğal yaşam için önemini sorgular", "Biyoçeşitliliği tehdit eden faktörleri, araştırma verilerine dayalı olarak tartışır”, "İnsan ve çevre arasındaki etkileşimin önemini ifade eder", "Yakın çevresindeki veya ülkemizdeki bir çevre sorununun çözümüne ilişkin öneriler sunar", "İnsan faaliyetleri sonucunda gelecekte oluşabilecek çevre sorunlarına yönelik çıkarımda bulunur", "İnsan-çevre etkileşiminde yarar ve zarar durumlarını örnekler üzerinde tartışır", "Doğal süreçlerin neden olduğu yıkıcı doğa olaylarını açıklar", "Yıkıcı doğa olaylarından korunma yollarını ifade eder" kazanımlarının doğrudan çevre eğitimine yönelik olduğu görülmektedir (MEB, 2018).

6. sınıf düzeyinde yer alan kazanımlar incelendiğinde "Dünya ve Evren" konu alanında yer alan "Güneş sistemindeki gezegenleri birbirleri ile karşılaştırır" kazanımı ile "Madde ve Doğası" konu alanında yer alan "Binalarda kullanılan 1sı yalıtım malzemelerinin seçilme ölçütlerini belirler", "Alternatif ısı yalıtım malzemeleri geliştirir", "Binalarda isı yalıtımının 
önemini, aile ve ülke ekonomisi ve kaynakların etkili kullanımı bakımından tartışır", "Yakıtları, katı, sıvı ve gaz yakıtlar olarak sınıflandırıp yaygın şekilde kullanılan yakıtlara örnekler verir", "Farklı türdeki yakıtların ısı amaçlı kullanımının, insan ve çevre üzerine etkilerini tartışır”, "Soba ve doğal gaz zehirlenmeleri ile ilgili alınması gereken tedbirleri araştırır ve rapor eder" kazanımlarının doğrudan çevre eğitimine yönelik olduğu görülmektedir (MEB, 2018).

7. sınıf düzeyine gelindiğinde "Dünya ve Evren" konu alanında "Uzay kirliliğinin nedenlerini ifade ederek bu kirliliğin yol açabileceği olası sonuçları tahmin eder" kazanımının; "Madde ve Doğası" konu alanında "Evsel atıklarda geri dönüştürülebilen ve dönüştürülemeyen maddeleri ayırt eder”, “Evsel katı ve sıvı atıkların geri dönüşümüne ilişkin proje tasarlar”, “Geri dönüşümü, kaynakların etkili kullanımı açısından sorgular", "Yakın çevresinde atık kontrolüne özen gösterir", "Yeniden kullanılabilecek eşyalarını, ihtiyacı olanlara iletmeye yönelik proje geliştirir" kazanımlarının ve "Fiziksel Olaylar" konu alanında yer alan “Güneş enerjisinin günlük yaşam ve teknolojideki yenilikçi uygulamalarına örnekler verir", "Güneş enerjisinden gelecekte nasıl yararlanılacağına ilişkin ürettiği fikirleri tartışır", "İnce ve kalın kenarlı merceklerin odak noktalarını deneyerek belirler (a. Ormanlık alanlara bırakılan cam atıklarının yangın riski oluşturabileceğine değinilir)" kazanımlarının doğrudan çevre eğitimine yönelik olduğu görülmektedir (MEB, 2018).

Son olarak 8. sinıf düzeyinde ise "Dünya ve Evren" konu alanında yer alan "Mevsimlerin oluşumuna yönelik tahminlerde bulunur", "İklim ve hava olayları arasındaki farkı açılar", "İklim biliminin (klimatoloji) bir bilim dalı olduğunu ve bu alanda çalışan uzmanlara iklim bilimci (klimatolog) adı verildiğini söyler” kazanımlarının; “Canlılar ve Yaşam” konu alanında yer alan "Örneklerden yola çıkarak mutasyonu açılar", "Örneklerden yola çıkarak modifikasyonu açıklar", "Mutasyonla modifikasyon arasındaki farklar ile ilgili çıkarımda bulunur", "Canlıların yaşadıkları çevreye uyumlarını gözlem yaparak açılar", "Madde döngülerini şema üzerinde göstererek açıklar", "Madde döngülerinin yaşam açısından önemini sorgular", "Küresel iklim değişikliklerinin nedenlerini ve olası sonuçlarını tartışır" kazanımlarının; "Madde ve Doğası" konu alanında yer alan "Asit yağmurlarının önlenmesine yönelik çözüm önerileri sunar (Asit yağmurlarının oluşum sebepleri ve sonuçlarına değinilir)" kazanımının ve "Fiziksel Olaylar" konu alanında yer alan "Elektrik enerjisinin bilinçli ve tasarruflu kullanılmasının aile ve ülke ekonomisi bakımından önemini tartışır" kazanımlarının doğrudan çevre eğitimine yönelik olduğu görülmektedir (MEB, 2018).

Sosyal bilgiler dersi öğretim programında yer alan "Birey ve Toplum" öğrenme alanı bir öğrencini içinde yaşadığı toplumun bir katılımcı bir üyesi olarak "ben" ve "biz" kavramını öğrenmesini bu yolla da içinde yaşadığı topluma karşı farkındalık yakalamasınıu hedefler. Sonraki öğrenme alanı olan "Kültür ve Miras"da öğrencilerin atalarının ve önceki medeniyetlerin 
bıraktığı kültürel miras ve bu mirasın korunması ile ilgili olduğu, öğrencileri geçmişleri ile ilgili bilgi sahibi yaparak onlara kendi geçmişlerini keşfetmeleri yolunda destek olmayı amaçlandığı söylenebilir (MEB, 2018).

Coğrafyaya ait konu ve coğrafi bilgilerin verildiği "İnsanlar, Yerler ve Çevreler" öğrenme alanında çevresel konular, coğrafi olaylar, coğrafi beceriler ve coğrafi tekniklerle ilgili kazanım beceri ve değerler vatandaşlık bağlamında öğrencilere sunulmaktadır. "Üretim, Dağıtım ve Tüketim" ise öğrencilerin bir üretici ve tüketici olarak var olduğu toplumdaki üretim, tüketim ve bu ikisi arasındaki süreçler de dahil olmak üzere meslekler, girişimcilik, ekonomik okuryazarlık gibi konularda bilgi, beceri ve değerleri benimseyerek hayatlarında kullanabilmelerine imkan sağlamayı hedefler (MEB, 2018).

"Etkin Vatandaşlık" aslında adından da anlaşılacağı üzere vatandaşlıkla ilgili olan konu, kazanım ve olaylar çerçevesinde öğrencilerin demokrasinin temelleri ile ilgili bilgiler edindiğpi bir öğrenme alanıdır. Bu öğrenme alanında etkin vatandaşlıkğın en önemli değerlerinden sorumluluk ve bağımsızlık gibi değerler ile katılımcılığı arttıracak iş birliği ve karar verme gibi becerileri öğrenciye sunulmaktadır. "Küresel Bağlantılar" öğrenme alanı yakından uzağa ülkesinin dış ilişkileri, ülkenin komşuları ve diğer kültürler gibi konular içermektedir (MEB, 2018).

4. sınıflarda "Kültür ve Miras" öğrenme alanında "Ailesi ve çevresindeki millî kültürü yansıtan ögeleri araştırarak örnekler verir", "Yakın çevresinde yer alan bir müze, cami, türbe, köprü, medrese, kervansaray gibi tarihî bir mekân gezisi ya da sözlü tarih veya yerel tarih çalışmaları yapılır" kazanımları; "İnsanlar, Yerler ve Çevreler" öğrenme alanında "Yaşadığı çevredeki doğal ve beşerî unsurları ayırt eder" kazanımı ve "Üretim, Dağıtım ve Tüketim" öğrenme alanında "Çevresindeki kaynakları israf etmeden kullanır" kazanımının çevre eğitimiyle ilgili olduğu görülmektedir (MEB, 2018).

5. sınıf düzeyinde "Kültür ve Miras" öğrenme alanında "Çevresindeki doğal varlıklar ile tarihî mekânları, nesneleri ve eserleri tanıtır" kazanımı ve "İnsanlar, Yerler ve Çevreler" öğrenme alanında "Yaşadığı yer ve çevresindeki doğal özellikler ile beşerî özelliklerin nüfus ve yerleşme üzerindeki etkilerine örnekler verir" kazanımı doğrudan; “Üretim, Dağıtım ve Tüketim" öğrenme alanında "Yaşadığı yer ve çevresindeki ekonomik faaliyetlere bağlı olarak gelişen meslekleri tanır" kazanımı ve "Küresel Bağlantılar" öğrenme alanında "Yaşadığı yer ve çevresinin ülkemiz ile diğer ülkeler arasındaki ekonomik ilişkilerdeki rolünü araştırır”, "Tarım, sanayi, turizm, ulaşım, eğitim, kültür endüstrisi gibi ekonomik faaliyet alanlarından uygun olanlara değinilir" kazanımları ise dolaylı olarak çevre eğitimi ile ilişkilidir (MEB, 2018). 
6. sınıf öğrenme alanlarından "İnsanlar, Yerler ve Çevreler" öğrenme alanında “Türkiye' nin temel beşerî coğrafya özelliklerini ilgili haritalar üzerinde gösterir", “Türkiye'nin nüfus dağılışı, ekonomik faaliyetleri, yer altı ve yer üstü kaynaklarına dair haritalar verilir", “Dünyanın farklı doğal ortamlarındaki insan yaşantılarından yola çıkarak iklim özellikleri hakkında çıkarımlarda bulunur”, “İnsanların yaşantılarına dair bilgi ve verilerden hareketle Akdeniz iklimi, kutup iklimi, muson iklimi ve ekvatoral iklim üzerine çıkarımda bulunulur" ve “Üretim Dağıtım Tüketim” öğrenme alanında "Kaynakların bilinçsizce tüketilmesinin canlı yaşamına etkilerini analiz eder" kazanımları çevre eğitimi ile ilişkilidir (MEB, 2018).

7. sınıflarda "İnsanlar, Yerler ve Çevreler" öğrenme alanında “Örnek incelemeler yoluyla göçün neden ve sonuçlarını tartışır" kazanımı; “Üretim Dağıtım Tüketim” öğrenme alanında "Üretimde ve yönetimde toprağın önemini geçmişten ve günümüzden örneklerle açıklar" kazanımı ve "Küresel Bağlantılar" öğrenme alanında "Arkadaşlarıyla birlikte küresel sorunların çözümüne yönelik fikir önerileri geliştirir" kazanımları çevre eğitimi ile ilişkilidir (MEB, 2018).

\section{TARTIŞMA, SONUÇ VE ÖNERILER}

Çevrenin ve beraberinde çevre eğitiminin tanımları incelendiğinde vurgulanan bir noktanın bu kavramların çok boyutlu ve disiplinler arası bir yapıya sahip olma durumları olduğu görülmektedir. Bu yönüyle birçok alandan araştırmacı tarafından ele alınan bir araştırma konusu olma niteliğine sahip olan çevre ve çevre eğitiminin, eğitim alanında okul öncesinden lisans ve lisansüstü eğitime kadar her düzeyde çalışılan bir araştırma konusu olduğu görülmektedir. Örneğin, Muşlu Kaygısız (2020) gerçekleştirdiği çalışmasında okul öncesi eğitim programında ve fen bilimleri dersi öğretim programınında çevre eğitimine yönelik kazanımlara yer verme durumları açısından ele almış ve mevcut programlardaki durumu ortaya koymaya çalışmıştır. Bahar, Erdaş Kartal ve Özel (2013) gerçekleştirdiği çalışmada Hayat Bilgisi dersi kapsamında çevre eğitimine yer verilme durumunu inceleyerek raporlamıştır. Öztürk ve Zayimoğlu Öztürk (2015) tarafından gerçekleştirilen çalışmada da sosyal bilgiler öğretim programının çevre eğitimi açısından analizi gerçekleştirilmiştir. Yükseköğretim boyutunda Yılmaz ve Sayhan (2018) tarafından gerçekleştirilen benzer bir çalışmada ise fen bilgisi ve sosyal bilgiler öğretmenliği lisans programları çevre eğitimi açısından değerlendirilmiştir. Ayrıca lisansüstü düzeyde çevre eğitiminin çeşitli yön ve boyutları ile yine farklı disiplinler altında birçok tez çalışması kapsamında araştırma konusu olarak ele alındığı görülmektedir. Gerçekleştirilen çalışmalarda dikkat edilmesi gereken önemli bir nokta ise okul öncesinde ve sonrasında ilk ve orta öğretim düzeyinde hayat bilgisi, sosyal bilgiler ve fen bilimleri dersleri kapsamında çevre eğitimine yer veriliyor olmasıdır. Dikkat edilmesi gereken bir diğer nokta ise bahsi geçen bu derslerin de, tıpkı çevre eğitiminde olduğu gibi, çok boyutlu ve disiplinler arası bir yapıya sahip olduğunun görülmesidir. Ayrıca eğitim ve öğretim programlarında çağın ihtiyaçları doğrultusunda çeşitli 
güncellemeler gerçekleştirilse de ifade edilen bu disiplinler altında çevre eğitiminin varlığını sürdürdüğünün görülmesidir.

Bu bağlamda gerçekleştirilen bu çalışma kapsamında Milli Eğitim Bakanlığı tarafından 2018 yılında güncellenerek uygulanmaya başlanan fen bilimleri ve sosyal bilgiler dersi öğretim programlarında özel amaçlar, yetkinlikler ve değerler, beceriler ve kazanımların yer aldığı konu ve öğrenme alanlarında çevre eğitimine yer verilme durumları incelenerek mevcut durum ortaya konulmuştur. Programlarda yer alan özel amaçlar incelendiğinde fen bilimlerinde ifade edilen 10 tane özel amaçtan 2 tanesinin; sosyal bilgilerde ifade edilen 18 tane özel amaçtan 1 tanesinin doğrudan çevre eğitimi ile ilişkili olduğu görülmektedir. Bu yönüyle toplamda disiplinler arası yapıya sahip olan bu derslerin ifade edilen özel amaçlarından yaklaşık olarak \%11'inin çevre eğitimine yönelik olduğu görülmektedir.

Ayrıca öğretim programlarında ifade edilen toplam 18 tane "değer"den 4 tanesi olan "duyarlılık", "sorumluluk", "tasarruf" ve "vatanseverlik" değerlerinin çevre eğitimine yönelik olduğu ve sürdürülebilir çevre anlayışına sahip bireylerin benimsemesi gereken temel kök değerler olduğu görülmekte ve yorumlanmaktadır. Bu yönüyle ifade edilen toplam değerler içerisinde yaklaşık olarak \%22'sinin çevre eğitimine yönelik olmasının çevre eğitimine verilen önem açısında oldukça önemli olduğu düşünülmektedir. Diğer yandan programlarda becerilerin ayrı ayrı ifade edildiği ve genellikle alana özgü beceriler olarak belirtildiği görülmektedir. Fen bilimleri öğretim programında yer alan beceriler incelendiğinde "bilimsel süreç becerileri", "yaşam becerileri" ve "mühendislik ve tasarım becerileri" olarak ifade edilen becerilerin doğrudan çevreye yönelik olmadığı fakat "çevre okuryazarı" bireyin sahip olması gereken "çevresinde karşılaştığı sorunların çözümünde aktif görev alma" yetkinliğinde olabilmesi için sahip olması gerektiği düşünülen beceriler olduğu görülmektedir. Bu bağlamda sosyal bilgiler öğretim programı incelendiğinde ifade edilen 27 beceriden 4 'ünün doğrudan veya dolaylı olarak çevre eğitimine yönelik olduğu söylenebilmektedir.

Öğretim programlarında ortak olarak ifade edilen yetkinliklerin "ana dilde iletişim", "yabancı dillerde iletişim", "matematiksel yetkinlik ve bilim/teknolojide temel yetkinlikler", "dijital yetkinlik”, “Öğrenmeyi öğrenme”, “Sosyal ve vatandaşlıkla ilgili yetkinlikler”, "inisiyatif alma ve girişimcilik" ve "kültürel farkındalık ve ifade" olmak üzere toplamda 8 tane olduğu görülmektedir. Tanımlanan bu yetkinlikler incelendiğinde doğrudan çevre eğitimi ile bir ilişki kurulamadığı görülse de, tıpkı becerilerde olduğu gibi, bütünsellik içerisinde değerlendirildiğinde bireyin çevreye karşı sorumluklarını yerine getirmesinde faydalı olacağı düşünülmektedir.

Son olarak ilgili öğretim programlarında yer alan konu ve öğrenme alanlarında ifade edilen kazanımlar çevre eğitimi açısından değerlendirilmiştir. Fen bilimleri öğretim programında 
belirlenen konu alanları altında farklı sınıf düzeylerinde farklı üniteler altında bir takım ilişkili kazanımlar ifade edilmiştir. Belirlenen konu alanlarının "Dünya ve Evren”, “Canlılar ve Yaşam”, "Fiziksel Olaylar" ve "Madde ve Doğası" olmak üzere 4 tane olduğu görülmektedir. Ayrıca sınıf düzeylerine göre bu konu alanları altında farklı ünite isimleri belirlenmiş ve bu ünitelere göre de kazanımlar belirlenmiştir. Bu yönüyle konu alanları altında, sınıf düzeyine göre değişmekle birlikte, toplamda sırasıyla 6, 12, 18 ve 6 ünite yer aldığı görülmektedir. Öğretim programının çok boyutlu yapıya ayrılmış olması da çevre eğitiminin birçok boyutuna yer verilebilmesine imkân sağlamış ve bu bağlamda ifade edilen tüm konu alanlarında her sınıf düzeyinde, farklı oranlarda da olsa, mutlaka yer verildiği görülmüştür. Sosyal bilgiler öğretim programı bu yönüyle incelendiğinde ise programda öğrenme alanı tanımları yapıldığı ve sınıf düzeyine göre ayrıca ünite ismi belirlenmeyerek doğrudan kazanım verilmesine gidildiği görülmektedir. Fakat ifade edilen kazanımlar sınıf düzeyine göre sarmal bir şekilde ilerlemiş ve birbiriyle bağlantılı olarak sunulmaya çalışılmıştır. Bu bağlamda ifade edilen kazanımlar sınıf düzeyine göre incelendiğinde sosyal bilgiler dersinin okutulduğu tüm sınıf düzeylerinde farklı öğrenme alanları altında çevre eğitimine yer verildiği görülmektedir. Bu yönüyle her iki öğretim programında da, derslerin okutulduğu tüm sınıf düzeylerinde çevre eğitimine yönelik kazanıma yer verildiği söylenebilmektedir. Bu da, disiplinler arası yapıya sahip olan bu iki dersin bireylerin "çevre okuryazarı" bireyler olarak yetiştirilmesi konusunda ne kadar önemli olduğunu göstermektedir.

Çevre eğitimi üzerine araştırma gerçekleştirmeyi planlayan araştırmacıların ilk ve ortaokul öğretim programlarında ve ders kitaplarında çevre eğitiminin yer alma ve merkezi sınavlarda sorgulanma durumları üzerine bir inceleme yapmalarının yararlı olabileceği düşünülmektedir. Ayrıca merkezi sınavlarda yer alan çevre eğitimine yönelik soruların, öğretim programlarında yer alan kazanımların, ders kitaplarında yer alan etkinlik ve değerlendirme sorularının hangi bilişsel düzeyde olduğunun incelenmesi yararlı olacaktır. Öyle ki, Uluslararası Matematik ve Fen Eğilimleri Araştırması'nda (TIMSS) fen bilimleri değerlendirme çerçevesi altında sorgulanan yer bilimi sorularının çevre eğitimi ile ilişki olduğu ve üst düzey düşünme becerileri gerektiren sorulardan oluşan bu sınavda yıllara göre en düşük puan ortalamasının genellikle bu alanda olduğu görülmektedir.

\section{KAYNAKÇA}

Akdur, R. (2005). Avrupa Birliği ve Türkiye'de çevre koruma politikalarn “Türkiye'nin Avrupa Birliğine иуити". ATAUM Araştırma Dizisi No: 23, Ankara Üniversitesi Basımevi, Ankara.

Akınoğlu, O., \& Sarı, A. (2009). İlköğretim programlarında çevre eğitimi. Marmara Üniversitesi Atatürk Eğitim Fakültesi Ĕ̆itim Bilimleri Dergisi, 30(30), 5-29. 
Aksoy, G., \& Taşkın, G. (2019). Öğretim programlarının değişmesini etkileyen faktörlerin, sosyal bilgiler ve fen bilimleri dersi müfredatlarını etkileme boyutu. Milli Eğitim Dergisi, 48(224), 75-99.

Atasoy, E. (2015). İnsan doğa etkileşimi ve çevre için eğitim. İstanbul: Sentez Yayıncılık.

Ateş, H. (2019). Fen bilimleri dersi öğretim programının sürdürülebilir kalkınma eğitimi açısından analizi. Yüzüncü Yıl Üniversitesi Eğitim Fakültesi Dergisi, 16(1), 101-127.

Bahar, M., Erdaş, E., \& Özel, R. (2013). İlköğretim hayat bilgisi programında çevre eğitimi. Abant İzet Baysal Üniversitesi Ĕ̆itim Fakültesi Dergisi, 13(2), 1-25.

Çiftçi, B., \& Dilek, A. (2005). 2005 ve 2018 Sosyal bilgiler öğretim programlarının coğrafi beceri ve coğrafi kazanım alanlarının karşılaştırılması. Eğitimde Yeni Yaklaşımlar Dergisi, 2(1), 33-59.

Çıray, F., Küçükyılmaz, E. A., \& Güven, M. (2015). Ortaokullar için güncellenen fen bilimleri dersi öğretim programına yönelik öğretmen görüşleri. Dicle Üniversitesi Ziya Gökalp Ĕ̆itim Fakültesi Dergisi, 25(31), 31-56.

Erkılıç, T. A. (2019). Değişim ve değerler eğitiminin gerekçeleri. İçinde A. F. Ersoy ve P. Ünivar (Eds.), Karakter ve değerler eğitimi (ss. 1-30). Ankara: Anı Yayıncılık.

Eroğlu, E., \& Yıldırım, H. İ. (2020). Argümantasyon tabanlı öğrenme yaklaşımının ortaokul 6. sınıf öğrencilerinin çevreye yönelik tutum, davranış ve başarılarına etkisi. Gazi Ĕ̆itim Bilimleri Dergisi, 6(1), 42-68.

Goldman, D., Yavetz, B., \& Pe'er, S. (2006). Environmental literacy in teacher training in Israel: environmental behavior of new students. The Journal of Environmental Education, 38(1), 322.

Görgen, İ. (2014). Program geliştirmede temel kavramlar. İçinde H. Şeker (Ed.), Eğitimde program geliştirme: kavramlar, yaklaşımlar (ss. 1-18). Ankara: Anı Yayıncılık.

Halstead, J. M., \& Taylor, M. J. (2000). Learning and teaching about values: A review of recent research. Cambridge Journal of Education, 30(2), 169-202.

Kan, Ç. (2010). ABD ve Türkiye'de sosyal bilgilerin tarihsel gelişimi. Gazi Üniversitesi Gazi Eğitim Fakültesi Dergisi, 30(2), 633-672.

Kaymakcı, S. (2009). Yeni sosyal bilgiler programı neler getirdi. Gazi Üniversitesi Gazi Eğitim Fakültesi Dergisi, 29(5), 1530-1545.

Milli Eğitim Bakanlığı (M.E.B.) (2018). Fen bilimleri dersi öğretim programı. Ankara: Milli Eğitim Bakanlığ1. 
Milli Eğitim Bakanlığı (M.E.B.) (2018). Sosyal bilgiler dersi öğretim programı. Ankara: Milli Eğitim Bakanlı̆̆ı.

Moseley, C. (2000). Teaching for environmental literacy. The Clearing House, 74(1), 23-24.

Muşlu Kaygısız, G. (2020). İlköğretim fen ve okul öncesi eğitim programlarındaki kazanımların çevre eğitimi açısından incelenmesi. Uluslararası Erken Çocukluk Ĕ̆itimi Çalışmaları Dergisi, $5(1), 29-47$.

Özçelik, D. A. (2014). Eğitim programları ve öğretim (3. Baskı). Ankara: Pegem Akademi Yayınları.

Öztürk, T., \& Zayimoğlu Öztürk, F. (2016). Sosyal bilgiler öğretim programının çevre eğitimi açısından analizi. Kastamonu Ĕ̆itim Dergisi, 24(3), 1533-1550.

Şardağ, M. (2020). Öğretim programlarıyla ilgili temel kavramlar. İçinde H. Ş. Ayvacı (Ed.), Fen öğretim programları (ss. 1-18). Ankara: Pegem Akademi.

Sönmez, V., \& Alacapınar F. G. (2018). Örneklendirilmiş bilimsel araştırma yöntemleri (5. Baskı). Ankara: Anı Yayıncilı.

Taşpınar, M. (2017). Kuramdan uygulamaya öğretim ilke ve yöntemleri (8. Baskı). Ankara: Pegem Akademi.

Teksöz, G., Şahin, E., \& Ertepinar, H. (2010). Çevre okuryazarlığı, öğretmen adayları ve sürdürülebilir bir gelecek. Hacettepe Üniversitesi Eğitim Fakültesi Dergisi, 39(39), 307-320.

Turan, S. (2019). 2018 Sosyal bilgiler öğretim programının disiplinlerarası yapısının incelenmesi. Journal of Innovative Research in Social Studies. 2(2), 166-190.

Üçüncü, G., \& Yılmaz, M., (2019). Ekolojik ayak izi kavramının kullanılmasının 7. sınıf öğrencilerinin çevreye yönelik tutumları ve tüketim tercihleri üzerine etkisi. Gazi Eğitim Bilimleri Dergisi, 5(2), 81-94.

Ürey, M., \& Aydın, M. (2014). İlköğretim fen ve teknoloji dersi programında yer alan çevre konularına yönelik bir program analizi. e-Kafkas Journal of Educational Research, 1(2), 7-20.

Yıldırım, M. (2020). Fen öğrenme ve öğretim yaklaşımları. İçinde H. Ş. Ayvacı (Ed.), Fen öğretme ve öğrenme yaklaşımları (ss. 1-14). Ankara: Pegem Akademi.

Yildırım, A., \& Şimşek, H. (2008). Sosyal bilimlerde nitel araştırma yöntemleri. Ankara: Seçkin Yayıncilik.

Yılmaz, O., \& Sayhan, H. (2016). Sosyal bilgiler ve fen bilgisi eğitimi lisans programlarının çevre eğitimi açısından değerlendirilmesi. Uluslararası Sosyal Bilgilerde Yeni Yaklaşımlar Dergisi, 2(2), 9-26. 
Etik Kurul Kararı: Gerçekleştirilen bu bilimsel çalışma kapsamında herhangi bir canlıdan herhangi bir yolla veri elde edilmediğinden dolayı etik kurul kararına gerek yoktur. 